\title{
THE CORRELATION OF READING INTEREST TO LEARNING OUTCOMES IN INDONESIAN LEARNER IN CLASS 5 of SDN 2 KARANG TANJUNG
}

\section{Laras Tazkiatul Amanah, Rizki Noviana, Rodatus Sofiah, Muhamad Chamdani}

Universitas Sebelas Maret

larastazkia04@gmail.com

Article History

accepted 30/09/2018

approved $12 / 10 / 2018$

published 30/10/2018

\section{Keywords}

reading interest, learning outcomes, learning

Indonesia

\begin{abstract}
Reading interest is main factor to increase quality of student. The study activities in the school, highly reading interest of student is a something hoped for all people. This study aimed to determine the correlation of reading interest to learning outcomes in Indonesian language. This research focused in a something impact of reading interest to learning outcomes. The method used is descriptive method with technic questionnaire, observation, and interview. Research sample were students of class 5 numbering 20 people. Students read well fall into the category with a percentage $78,86 \%$ while the study result in the category fairly with the average value of 58,9. Based on the correlation test with significance level $\alpha=5 \%$ concluded there is a correlation between reading interest by learning outcomes in learning Indonesian fifth grade students of State Elementary School 2 Karang Tanjung with $r$ table $\geq r$ count or $0.444 \geq 0.029$.
\end{abstract}

Social, Humanities, and Education Studies (SHEs): Conference Series https://jurnal.uns.ac.id/shes
p-ISSN 2620-9284

e-ISSN 2620-9292 


\section{PENDAHULUAN}

Perkembangan ilmu pengetahuan dan teknologi menuntut terciptanya masyarakat yang gemar membaca. Membaca merupakan kegiatan untuk memperoleh informasi pengetahuan yang sangat berguna bagi kehidupan terutama pendidikan. Masyarakat yang gemar membaca akan memperoleh pengetahuan dan wawasan sehingga akan meningkatkan kecerdasan masyarakat. Menurut Burns, dkk (Rahim, 2009) mengemukakan bahwa "kemampuan membaca merupakan sesuatu yang vital dalam suatu masyarakat terpelajar. Namun, anak-anak yang tidak memahami pentingnya belajar membaca tidak akan termotivasi untuk belajar." Dalam dunia pendidikan membaca adalah keterampilan yang harus dikuasai siswa karena merupakan modal dasar untuk mempelajari seluruh mata pelajaran di sekolah. Hal ini sejalan dengan pendapat Jenna Hallma (Deviana, 2017) yang menyatakan bahwa, "Membaca adalah tujuan fundamental yang anak-anak harus kuasai agar bisa berhasil di sekolah dan dalam kehidupan".Dengan membaca akan meningkatkan pemahaman siswa terhadap materi pembelajaran. Kauffman (2015:3) mengemukakan bahwa "anak yang lebih sering membaca akan mempunyai kosakata yang lebih banyak dan memiliki kemampuan yang lebih daripada anak yang kurang membaca".

Membaca merupakan keterampilan yang harus dikembangkan secara berkesinambungan yang dapat diperoleh melalui belajar, tahap demi tahap, dalam waktu yang panjang secara terus menerus. Motivasi merupakan faktor yang cukup besar pengaruhnya terhadap kemampuan membaca. Orang yang memiliki motivasi yang tinggi, dia akan giat belajar membaca dan memiliki minat yang tinggi. Selain motivasi, terdapat faktor-faktor yang mempengaruhi hasil belajar siswa (Syah, 2015:146) terdiri dari faktor internal dan eksternal. Faktor internaladalah faktor yang berasal dari dalam diri siswa sendiri, meliputi 2 aspek yakni ; Aspek fisiologis (yang bersifat jasmani) dan aspek psikologis (yang bersifat rohani). Aspek rohani terdiri dari ; 1) tingkat kecerdasan atau Intelegensi (IQ) siswa tak dapat diragukan lagi, sangat menentukan tingkat keberhasilan tingkat belajar siswa. Ini bermakna, semakin tinggi kemampuan intelegensi seorang siswa maka semakin besar peluangnya untuk meraih sukses. Sebaliknya, semakin rendah kemampuan intelegensi seorang siswa maka semakin kecil peluangnya untuk memperoleh sukses.2) sikap siswa, sikap siswa yang positif terhadap mata pelajaran tertentu merupakan pertanda awal yang baik bagi proses belajar siswa tersebut. Sebaliknya sikap negatif siswa terhadap mata pelajaran, apalagi jika diiringi kebencian maka dapat menimbulkan kesulitan belajar siswa.3) bakat siswa, secara global bakat itu mirip dengan intelegensi karena merupakan pembawaan sejak lahir. Sehubungan dengan hal itu, bakat akan dapat mempengaruhi tinggi rendahnya prestasi belajar bidang-bidang studi tertentu.4) minat siswa, minat seorang siswa dapat mempengaruhi kualitas pencapaian hasil belajar siswa dalam bidang studi tertentu, dan 5) motivasi, dapat menolong siswa untuk belajar sehingga akan menyebabkan siswa lebih bersemangat dalam melakukan proses pembelajaran.Adapun faktor eksternal sendiri meliputi 1) faktor lingkungan sosial; lingkungan sosial yang lebih banyak mempengaruhi kegiatan belajar ialah orang tua dan keluarga itu sendiri. Kondisi keluarga dapat memberikan dampak baik ataupun buruk terhadap kegiatan belajar dan hasil yang dicapai oleh siswa, 2) faktor lingkungan non sosial meliputi keadaan cuaca, fasilitas belajar, dan kondisi gedung sekolah.

Minat baca ialah keinginan yang kuat disertai usaha-usaha seseorang untuk membaca. Orang yang mempunyai minat membaca yang kuat akan diwujudkannya dalam kesediaannya untuk mendapat bahan bacaan dan kemudian membacanya atas kehendaknya sendiri (Rahim, 2009). Dai (2013:165) menambahkan "minat membaca bisa berarti perhatian dan keingin tahuan terhadap suatu subjek, aktivitas, orang, pikiran, atau tempat yang diperoleh dari kegiatan membaca". 
Berdasarkan penelitian yang dilakukan pada siswa kelas V (Lima) Sekolah Dasar Negeri 2 Karang Tanjung mengenai hubungan antara minat baca dan hasil belajar diharapkan dapat memberikan informasi akurat mengenai minat baca siswa sehingga peneliti bisa mengklasifikasikan minat baca siswa tersebut pada tingkat tinggi atau rendah. Selain itu, penelitian ini juga diharapkan dapat menunjukkan ada atau tidaknya korelasi antara minat baca siswa dengan hasil belajarnya pada pembelajaran bahasa Indonesia.

\section{METODE}

Metode yang digunakan dalam penelitian ini adalah metode deskriptif. Bentuk penelitian yang digunakan berdasarkan metode yang dipilih yaitu studi hubungan (interrelationship studies) dengan bentuk studi korelasi. Populasi dalam penelitian ini adalah siswa SD N 2 Karang Tanjung yang berjumlah 136 siswa. Sampel dalam penelitian ini adalah siswa Kelas V (Lima) yang berjumlah 20 siswa. Teknik pengumpulan data yaitu teknik komunikasi tidak langsung dan teknik studi dokumenter. Instrumennya adalah angket yang terdiri dari 10 pernyataan dan dokumen nilai ulangan tengah semester Bahasa Indonesia. Adapun teknik analisis data mengenai minat baca siswa dianalisis menggunakan rumus persentase menurut Purwanto (2013:102) berikut ini :

Keterangan :

$$
\mathrm{NP}=\frac{\mathrm{R}}{\mathrm{SM}} x 100
$$

$\mathrm{NP}=$ Nilai persen yang dicari atau diharapkan

$\mathrm{R}=$ Skor mentah yang diperoleh siswa

$\mathrm{SM}=$ Skor maksimum ideal dari tes yang bersangkutan

100 = Bilangan tetap

Analisis hasil belajar siswa pada pembelajaran bahasa Indonesia menggunakan rumus rata-rata menurut Rajagukguk (2015) berikut:

$$
X^{-}=\frac{\sum \mathrm{X}}{N}
$$

Keterangan

$X^{-}=$Rata-rata hitung yang dicari

$\sum X=$ Jumlah skor

$\mathrm{N}=$ Jumlah subjek

Untuk mengetahui ada atau tidaknya hubungan antara kedua variabel, maka digunakan rumus korelasi pearson product moment menurut Rajagukguk (2015: 103) sebagai berikut :

$$
r=\frac{\mathrm{n}\left(\sum \mathrm{XY}\right)-\left(\sum \mathrm{X}\right)\left(\sum \mathrm{Y}\right)}{\sqrt{n\left[\left(\sum X^{2}\right)-\left(\sum X\right)^{2}\right]\left[\left(\sum Y^{2}\right)-\left(\sum Y\right)^{2}\right]}}
$$

Keterangan :

$\mathrm{n} \quad=$ Jumlah data (responden)

$\mathrm{x}=$ Variabel bebas

$\mathrm{y} \quad=$ Variabel terikat

HASIL DAN PEMBAHASAN

Penelitian dilaksanakan pada tanggal 29 September 2018 di kelas V (Lima). Pada waktu yang ditentukan, peneliti memberikan angket minat baca (variable $X$ ) kepada semua siswa untuk diisi sesuai pengalaman pribadinya kemudian langsung 
dikumpulkan. Jumlah item pertanyaan dalam angket adalah 10 item dengan skor jawaban 1 sampai 4 sehingga rentang skor yang mungkin diperoleh adalah 10 sampai 40. Skor minimal ideal adalah 10 dan skor maksimalnya adalah 40 . Skor minimal minat baca (min) yang diperoleh siswa yaitu 24, skor maksimalnya (max) 40, rata-ratanya (mean) 31,8 dan modusnya (Mo) 31. Ini menunjukkan bahwa tidak ada siswa yang minatnya sangat rendah. Adapun indikator yang digunakan untuk menentukan perolehan skor dari masing-masing aspek berdasarkan jawaban siswa di angket adalah sebagai berikut.

1. Saya senang membaca buku dimanapun saya berada

2. Saya selalu bersemangat dalam membaca buku

3. Saya perlu nilai baik jadi saya harus rajin baca buku

4. Saya merasa wajib baca buku, karena saya anak sekolah

5. Saya harus baca buku, karena membuat saya pintar

6. Saya tertarik dengan buku-buku pengetahuan

7. Saya selalu ingin membaca buku di Perpustakan

8. Saya tertarik dengan buku yang ada di perpustakaan

9. Pada hari libur saya tetap baca buku

10. Saya ingin mendatangi perpustakaan yang lebih lengkap dari perpustakaan yang ada di sekolah

Dari persentase yang diperoleh, diinterpretasikan dan diklasifikasi dengan pedoman penilaian yang diadaptasi dari pendapat Purwanto (2013:103) berikut ini :

Tabel 1. Pedoman Pengklasifikasian Minat Baca

\begin{tabular}{ccc}
\hline No & Presentase & Kategori \\
\hline 1 & $86-100 \%$ & Sangat Baik \\
2 & $76-85 \%$ & Baik \\
3 & $60-75 \%$ & Cukup \\
4 & $55-59 \%$ & Kurang \\
5 & $\leq 54 \%$ & Kurang Sekali \\
\hline
\end{tabular}

Berdasarkan data dari angket minat baca kelas V (Lima) SD Negeri 2 Karang Tanjung yang telah dihitung, berikut ini adalah hasil persentasenya :

Tabel 2. Hasil Persentase minat baca

\begin{tabular}{|c|c|c|c|c|c|}
\hline No & PERNYATAAN & $\begin{array}{c}\text { Skor } \\
\text { mentah }\end{array}$ & $\begin{array}{c}\text { Skor } \\
\text { maksimum }\end{array}$ & $\begin{array}{c}\text { Nilai } \\
\text { persentase }\end{array}$ & Kategori \\
\hline 1 & $\begin{array}{l}\text { Saya senang membaca } \\
\text { buku dimanapun saya } \\
\text { berada }\end{array}$ & 61 & 80 & $76,25 \%$ & Baik \\
\hline 2 & $\begin{array}{l}\text { Saya selalu bersemangat } \\
\text { dalam membaca buku. }\end{array}$ & 66 & 80 & $82,5 \%$ & Baik \\
\hline 3 & $\begin{array}{l}\text { Saya perlu nilai baik jadi } \\
\text { saya harus rajin baca buku }\end{array}$ & 68 & 80 & $85 \%$ & Baik \\
\hline 4 & $\begin{array}{l}\text { Saya merasa wajib baca } \\
\text { buku, karena saya anak } \\
\text { sekolah }\end{array}$ & 67 & 80 & $83,75 \%$ & Baik \\
\hline 5 & $\begin{array}{l}\text { Saya harus baca buku, } \\
\text { karena membuat saya } \\
\text { pintar }\end{array}$ & 69 & 80 & $86,25 \%$ & $\begin{array}{l}\text { Sangat } \\
\text { baik }\end{array}$ \\
\hline 6 & $\begin{array}{l}\text { Saya tertarik dengan buku- } \\
\text { buku pengetahuan }\end{array}$ & 59 & 80 & $73,75 \%$ & Cukup \\
\hline
\end{tabular}


7 Saya selalu ingin membaca buku di Perpustakan

8 Saya tertarik dengan buku yang ada di perpustakaan

9 Setiap ada waktu luang saya perlu baca buku

10 Saya ingin mendatangi perpustakaan yang lebih lengkap dari perpustakaan yang ada di sekolah
65

80

$81,25 \%$

Baik

61

80

$76,25 \%$

Baik

61

80

$76,25 \%$

Baik

61

80

$76,25 \%$

Baik

Berdasarkan data hasil penelitian yang disajikan dalam tabel 2, kita ketahui bahwa secara keseluruhan minat baca siswa kelas V (Lima) ini "baik". Hal ini terlihat dari indikator yang diberikan. Sebanyak 7 indikator masuk kategori baik, 1 indikator sangat baik, dan 2 indikator masuk kategori cukup.

Data yang diperoleh dari hasil belajar siswa (nilai ulangan tengah semester pelajaran bahasa Indonesia) dikategorikan berdasarkan tolok ukur rata-rata berikut ini (BSNP, dalam Deviana, 2017) :

Tabel 3. Tolok Ukur Kategori Penilaian Rata-rata Hasil Belajar

\begin{tabular}{cc}
\hline Skor & Keterangan \\
\hline $86-100$ & Baik sekali \\
$71-85$ & Baik \\
$56-70$ & Cukup \\
$41-55$ & Kurang \\
$<40$ & Sangat kurang \\
\hline
\end{tabular}

Tabel 4. Hasil Rekap nilai UTS Bahasa Indonesia Kelas V (Lima)

\begin{tabular}{lc}
\hline \multicolumn{1}{c}{ Kategori } & Skor/Nilai \\
\hline Jumlah & 1.178 \\
Nilai rata-rata & 58,9 \\
Nilai tertinggi & 82 \\
Nilai terendah & 28 \\
Modus & 68
\end{tabular}

Nilai rata-rata yang diperoleh seluruh siwa ini termasuk ke dalam kategori cukup. Berikut ini adalah uraian persentasenya:

1. Responden yang memperoleh nilai dalam rentang 86 - 100 dengan kategori sangat baik tidak ada.

2. Responden yang memperoleh nilai dalam rentang 71 - 85 dengan kategori baik berjumlah 3 orang dengan persentase $15 \%$.

3. Responden yang memperoleh nilai dalam rentang $56-70$ dengan kategori cukup berjumlah 11 orang dengan persentase $55 \%$.

4. Responden yang memperoleh nilai dalam rentang 41 - 55 dengan kategori kurang berjumlah 3 orang dengan persentase $15 \%$.

5. Responden yang memperoleh nilai $<40$ dengan kategori sangat kurang berjumlah 3 orang, dengan persentase $15 \%$. 
Dari seluruh responden di atas yaitu 20 siswa, terdapat 13 siswa yang belum mencapai KKM atau nilainya kurang dari 65.

Untuk mengetahui tingkat hubungan antara variabel bebas $(X)$ yaitu minat baca siswa dengan variabel terikat $(\mathrm{Y})$ yaitu hasil belajar siswa, ditentukan dengan kriteria sebagai berikut :

Tabel 5. Kriteria Tolok Ukur Tingkat Korelasi dan Kekuatan Hubungan

\begin{tabular}{cc}
\hline Nilai Korelasi $(\mathbf{r})$ & Tingkat Hubungan \\
\hline $0,000-0,199$ & Sangat rendah \\
$0,200-0,399$ & Rendah \\
$0,400-0,599$ & Sedang \\
$0,600-0,799$ & Kuat \\
$0,800-1,000$ & Sangat kuat \\
\hline
\end{tabular}

Sugiyono (2014:183)

Perhitungan korelasi antara minat baca dengan hasil belajar siswa dari tabel persiapan perhitungan korelasi diperoleh

$$
\begin{array}{lll}
\sum X=638 & \sum Y=1.178 & \sum X Y=37.608 \\
\sum X^{2}=20.630 & \sum Y^{2}=73.068 & N=20
\end{array}
$$

Data ini kemudian dihitung menggunakan rumus korelasi product moment menurut Rajagukguk (2015 : 103) sebagai berikut:

$$
r=\frac{\mathrm{n}\left(\sum \mathrm{XY}\right)-\left(\sum \mathrm{X}\right)\left(\sum \mathrm{Y}\right)}{\sqrt{n\left[\left(\sum X^{2}\right)-\left(\sum X\right)^{2}\right]\left[\left(\sum Y^{2}\right)-\left(\sum Y\right)^{2}\right]}}
$$

Sehingga diperoleh $r=0,029, r$ tabel dengan taraf signifikansi $5 \%$ untuk $N=20$ adalah 0,44 dan $r$ hitung yang diperoleh adalah 0,029 sehingga $r$ hitung lebih kecil dari $r$ tabel. Ini menunjukkan bahwa terdapat korelasi antara minat baca dengan hasil belajar pada pembelajaran bahasa Indonesia siswa kelas V (Lima) Sekolah Dasar Negeri 2 Karang Tanjung.

Ada banyak faktor yang bisa mempengaruhi hasil belajar siswa, baik itu faktor internal maupun faktor eksternal. Berdasarkan hasil perhitungan koefisien korelasi determinasi diperoleh $r^{2}=0,0841$ yang artinya pengaruh minat baca terhadap hasil belajar siswa hanya $8,4 \%$, sedangkan $91,6 \%$ nya dipengaruhi oleh variable lain yang tidak terdesain dalam penelitian. Ini menunjukkan bahwa faktor lain yang mempengaruhi hasil belajar siswa harus lebih diperhatikan karena memberikan kontribusi yang lebih besar daripada minat baca yang diteliti.

Minat baca yang tinggi tidak selalu memberikan hasil belajar yang tinggi karena tergantung dari jenis bacaan yang dibaca oleh siswa. Sehingga perlu dilakukan penelitian lebih lanjut yang dapat mengungkap jenis-jenis bahan bacaan yang banyak digemari siswa.

\section{SIMPULAN}

Berdasarkan hasil penelitian yang dilakukan dapat disimpulkan bahwa minat baca siswa kelas V (Lima) Sekolah Dasar Negeri 2 Karang Tanjung yang terdiri dari 10 indikator minat baca siswa termasuk dalam kategori baik. Rata-rata hasil belajar siswa dalam hal ini nilai ulangan tengah semester pelajaran bahasa Indonesia memperoleh kategori cukup dengan nilai rata-rata 58,9. Tidak terdapat korelasi yang signifikan antara minat baca dengan hasil belajar pada pembelajaran bahasa Indonesia siswa kelas V (Lima) Sekolah Dasar Negeri 2 Karang Tanjung. Hal ini diketahui dari perolehan nilai koefisien korelasi (rhitung) $=0,029$ yang lebih kecil dibandingkan $r$ tabel 
$=0,444$ pada taraf signifikansi $5 \%$. Berdasarkan hasil perhitungan koefisien korelasi determinasi diperoleh $r^{2}=0,0841$ yang artinya pengaruh minat baca terhadap hasil belajar siswa hanya 8,4\%, sedangkan 91,6 \% nya dipengaruhi oleh variable lain yang tidak terdesain dalam penelitian. Ini menunjukkan bahwa faktor lain yang mempengaruhi hasil belajar siswa harus lebih diperhatikan karena memberikan kontribusi yang lebih besar daripada minat baca yang diteliti. Sehingga nilai korelasi ini termasuk ke dalam tingkat hubungan yang rendah.

\section{DAFTAR PUSTAKA}

Dai, Wenji. 2013. Correlates of the Reading Interest of Chinese High School Students in International Schools. Jurnal Asian Social Science; Vol. 9, No. 3; 2013. ISSN 1911-2017 E-ISSN 1911-2025

Deviana, Eka. 2017. Korelasi Minat Baca dengan Hasil Belajar pada Pembelajaran Bahasa Indonesia Siswa Kelas III SD. Universitas Tanjungpura

Kauffman,Syndi. 2015. Story Elements: Which Impact Children's Reading Interests?. Diunduh dari https://etd.ohiolink.edu/rws etd/document/get/bgsu1120575730/inline\&sa.pdf pada tanggal 11 Oktober 2018.

Purwanto, Ngalim. 2013. Prinsip-Prinsip dan Teknik Evaluasi Pembelajaran. Bandung : PT Remaja Rosdakarya

Rahim, Farida. 2009. Pengajaran Membaca di Sekolah Dasar. Jakarta : Bumi Aksara Rajagukguk, Waminton. 2015. Evaluasi Hasil Belajar Matematika. Yogyakarta : Media Akademi

Retariandalas. 2017. Pengaruh Minat Membaca dan Motivasi Belajar terhadap Prestasi Belajar IPA Siswa. Jurnal Formatif 7 (2) : 190-197, 2017. ISSN : 2088-351X.

Sugiyono. 2014. Statistika untuk Penelitian. (Cetakan ke-25). Bandung: Alfabeta

Syah, Muhibbin. 2015. Psikologi Belajar. Depok : PT Raja Grafindo Persada. 